\title{
Metaphors of Fine Arts in Amitav Ghosh's Dancing in Cambodia, At Large in Burma
}

\section{Suhasini Vincent}

\section{(2) OpenEdition \\ 1 Journals}

Electronic version

URL: https://journals.openedition.org/ces/8730

DOI: $10.4000 /$ ces. 8730

ISSN: 2534-6695

\section{Publisher}

SEPC (Société d'études des pays du Commonwealth)

\section{Printed version}

Date of publication: 1 September 2009

Number of pages: $77-86$

ISSN: 2270-0633

\section{Electronic reference}

Suhasini Vincent, "Metaphors of Fine Arts in Amitav Ghosh's Dancing in Cambodia, At Large in Burma", Commonwealth Essays and Studies [Online], 32.1 | 2009, Online since 23 December 2021, connection on 17 February 2022. URL: http://journals.openedition.org/ces/8730 ; DOI: https://doi.org/10.4000/ ces. 8730

\section{(c) $(1) \odot$}

Commonwealth Essays and Studies is licensed under a Licence Creative Commons Attribution - Pas d'Utilisation Commerciale - Pas de Modification 4.0 International. 


\section{Metaphors of Fine Arts in Amitav Ghosh's \\ Dancing in Cambodia, At Large in Burma}

This paper is a study of how Amitav Ghosh weaves together personal accounts of individuals caught in the conflict of history in his travelogue Dancing in Cambodia, At Large in Burma. Identifying the author's need to uncover stories new and old, break down artificial political boundaries and dissolve distances in time and space to bring new worlds within our reach, my paper will consider how these configurations are presented in these essays through metaphors of fine arts.

mitav Ghosh, an Indian writer who has resided in India, Alexandria,
Oxford and Brooklyn, has won various literary awards for his novels
and essays. ${ }^{1}$ Following the trend set by other diasporic authors like Salman Rushdie, Vikram Seth, V.S. Naipaul and Pico Iyer, whose travel writing displays a globalised perspective, Amitav Ghosh pens his account of travel in Cambodia and Burma in a collection of essays entitled Dancing in Cambodia, At Large in Burma. ${ }^{2}$ I will see how the writer "establishes a set of features which allow us to recognize the account of travel as a distinct literary genre and to appreciate its specific qualities - including a striking potential to be continually revitalized" (Korte 4). Ghosh uses the form of the travel essay to record his wanderlust in Cambodia and Burma, making ample use of the genre's particular potential to assemble a wealth of observations, globetrotter experiences and postcolonial reflections. Ghosh's accounts depict a journey in its course of events and takes the reader through the same circuit of experience. My study will consider how Ghosh presents dance as a symbol of the continuity of culture in Cambodia and how this art form serves as a catalyst of cultural and political resistance in the first piece "Dancing in Cambodia". I shall also evoke the European perception of Cambodia through Ghosh's evocation of Rodin's celebrated paintings of the first official

1. Ghosh received the French Prix Médicis Etranger and the New York Times Notable Book Award of the year for his first book, The Circle of Reason (1986). The Shadow Lines won the 1990 Kendra Sahitya Akademi Award and the Ananda Puraskar. The Calcutta Chromosome was awarded the Arthur C. Clarke Award for best science fiction. His essay "The March of Novel Through History: The Testimony of My Grandfather's Bookcase" was awarded the Pushcart Prize in 1999. The Glass Palace won the Grand Prize for Fiction at the Frankfurt International e-Book Awards in 2001. The Hungry Tide received the Hutch Crossword Book Prize in 2006. In 2007, Amitav Ghosh was awarded the Grinzane Cavour Prize in Turin, Italy. His latest novel The Sea of Poppies was shortlisted for the Booker Prize in 2008. He received the prestigious Padma Shri Award from the Indian Government in 2007 for outstanding contribution in the field of Literature.

2. Unspecified paginations provided in the text refer to Ghosh's Dancing in Cambodia, At Large in Burma. 
Cambodian visit to Paris in 1906. My reading between the lines of "Stories in Stone" will identify how Ghosh's narrative artifice mingles metaphors of sculpture with forgotten stories of the past that inspire heroism in later generations. I will also consider how 'travel' has inspired the author to voice the need for democracy in Burma in the final essay "At Large in Burma". ${ }^{3}$ This paper will thus concern itself with the essay as an ideal mode for presenting cultural turmoil, postcolonial historic perspective, experiences of travel and political reportage. It will show how Ghosh's postmodern sleight of hand deftly mingles strands of history with the cultural threads of the fine arts.

Dancing in Cambodia, At Large in Burma (1998) coincides with the death of Pol Pot, the leader of the Cambodian communist movement. Ghosh's essays engage with dance's political and cultural roles, its near destruction by Pol Pot, its politicization under the Vietnamese Communists, and its revival today. The first essay, "Dancing in Cambodia", presents the grandeur of Cambodia in 1906 as seen through the eyes of the French, when King Sisowath of Cambodia boarded the French liner, Amiral-Kersaint, to take his entourage to Marseille for the Exposition Coloniale. Ghosh renders the European perception of the Orient by means of an enumeration: "no pasha or prince or bey had aroused nearly as much enthusiasm as the King of Cambodia" (2). ${ }^{4}$ In his essay entitled "The Grain of the Voice," Roland Barthes writes, "The 'grain' is the body in the singing voice, in the writing hand, in the performing limb" (276). Similarly Ghosh's essayist-eye identifies and examines the 'grains' in Cambodian dance technique and revels in the new, young communities it generates. Ghosh's account quotes Le Figaro and details how during the reception given by the Minister of Colonies in the Bois de Boulogne in Paris, an enraptured Rodin compared the perfection of the dance postures to those of the Greeks:

While the performance was in progress a correspondent spotted the most celebrated Parisian of all in the audience, the bearded mosaic figure of the 'great Rodin ... going into ecstasies over the little virgins of Phnom Penh, whose immaterial silhouettes he drew with infinite love ...' 'These Cambodians have shown us everything that antiquity could have contained', he wrote afterwards. 'It is impossible to think of anyone wearing human nature to such perfection; except them and the Greeks'. (37)

The focus on dance in Cambodia is spiced with accounts from Le Figaro showing Western perception. The travelogue is thus enriched with texts from other sources rather than actual experience. It is interesting to read Ghosh's original source, Rodin et les danseuses cambodgiennes: Sa dernière passion, in which one of the

3. My study of 'travel' as a fine art draws inspiration from Barbara Korte's study in English Travel Writing: From Pilgrimages to Postcolonial Explorations, in which she describes the act of travelling as a fine art form that favours the "phenomena of inter-culturality" (2).

4. The volume of essays Dancing in Cambodia, At Large in Burma displays Rodin's sketch of a Cambodian dancer on its front cover and five other coloured sketches appear inside. 
contributors, Dominique Viéville, describes Rodin's sketches as an attempt at resurrecting works of antiquity, unveiling the mysteries of the past and finding perfection in Cambodian dance postures that could be equalled only by those of Ancient Greece. Viéville claims that Cambodian dance would have the capacity to ressuscitate the mysterious figures from the past ${ }^{5}$. Through metaphors of dance, Ghosh's descriptive endeavour draws inspiration from Rodin's one hundred and fifty sketches to compare the oriental dance postures of the Phnom Penh dancers with the Greek silhouettes of antiquity. The reader visualises how Rodin's sketches capture the timeless aesthetics of Cambodian classical dance on paper where myriad movements relate stories that were born in the Hindu temples of Angkor, going back to an era when royal court dances symbolized and affirmed the connection between heaven and earth. The essay pays tribute to the hybrid melange of two traditions, Rodin's modernity and traditional Khmer art.

In "Dancing in Cambodia," Ghosh addresses two facets of Cambodia, the rich golden past of Khmer culture and the sad present. The juxtaposition of incidents from the glorious past and the present suggests how the dancers draw inspiration from the past to face the present and the future. The essay shows how dance bridges the gap between generations, penetrates barriers and finds a connecting web of patterns in apparently unconnected events. Ghosh weaves a strand of dance episodes to link the 1906 visit of Cambodia's King Sisowath and his entourage of Cambodian classical dancers to France, the land of the colonizer, with the recent history of the country decimated by the Khmer Rouge Revolution. ${ }^{6}$ On 18 March 1970, after a military coup, King Sihanouk was sent into exile and the presence of dance in the country was subsequently erased. During the destructive rule of the Khmer Rouge from 1975 to $1979,1.7$ million Cambodians, that is nearly one-third of the population of Cambodia, lost their lives. During this period, the Khmer Rouge abolished "private property, personal possessions, money, leisure, socializing, marriage (except in cadre-approved cases), religion, and all personal liberties" (Widyono 26). During the dictatorship of Pol Pot, former palace dancers went into hiding for fear of execution, as their association with such royal traditions as dance was considered a negative element in the wake of the agrarian revolution. In January 1979, the Vietnamese invaded

5. "La danse cambodgienne, dans son altérité, aurait, pour Rodin, cette capacité à faire renaître les figures mystérieuses du passé” (9).

6. In 1863, King Norodom of Cambodia sought the protection of France to end the Thai and Vietnamese occupation. In 1867 after French intervention, Thailand renounced its hold over Cambodia in exchange for the control of Battambang and Siem Reap provinces which were a part of Thailand until 1906. In 1906, in a border treaty signed between France and Thailand, these provinces were ceded back to Thailand. King Sisowath's visit to the Exposition Coloniale coincides with the period just after the signing of this treaty. Cambodia was a protectorate of France from 1863 to 1953 and administered as a part of French Indo-China. It gained independence from France on November 9, 1953 (Rooney 48, Braquet 33). 
Cambodia and drove out the Khmer Rouge and the handful of surviving artists formed troupes hoping to re-create their precious art forms. Ghosh's account hinges upon the three actors who shaped the destiny of Cambodia: the erstwhile King Sihanouk (b. 1922), the Khmer Rouge (1975-79), and the United Nations, notably the United Nations Transitional Authority on Cambodia (UNTAC1992-93). The political interactions of the three forces are like 'dancing shadows' shaping the destiny of Cambodia. In Dancing Communities: Performance, Difference and Connection in the Global City, Judith Hamera writes, "Every day, urban communities are danced into being. This is more than a metaphor. It is a testament to the power of performance as a social force, as cultural poeisis, as communication infrastructure that makes identity, solidarity and memory shareable" (1). I will now examine how dance serves as a testimony to the power of performance as a social force in Ghosh's essay. While interviewing Cambodian survivors like the famous Cambodian court dancer, Pol Pot's sister-in-law, Chea Samy, who had been trained in classical dance since the age of six under the supervision of Princess Soumphady, Ghosh traces and retraces forgotten history on a slattered slate. Pieces of lost history come to light as they are danced into being. While describing a dancer in Phnom Penh teaching a troupe of forty boys and girls, Ghosh shows how dance can inspire a nation to rebuild itself. The dance teacher deftly springs into action resurrecting a lost art form, fashions like clay and chisels out from rough stone a new generation of dancers, making identity, solidarity and memory shareable. "Occasionally she would spring off the bench and bend back a dancer's arm, or push in a waist, working as a sculptor does, by touch, moulding the limbs like clay" (6). With a generation of dance teachers wiped out by the Pol Pot regime, Ghosh shows how the challenge lay in reviving the traditional art form. Dance becomes a trope for the indestructibility of the culture threatened with extinction during the Pol Pot era. Ghosh focuses on the thoughts of a dancer who fantasises in her dreams. The fine art form becomes a dance of imagination capable of stirring forgotten memories in the mind's misty depths. Dance also brings in images of stoic patience, dogged persistance and years of hard toil and labour to perfect gestures and postures. The act of resurrecting the Khmer art form entails further acts of reconstruction, recreation and reconfiguration. Ghosh examines Chea Samy's need to pass on the art to children as this serves as a means of inserting herself meaningfully into history. Her triumph lies in the successive passing on of the art to the present young generation in spite of the various trials faced in the past. The essay relates how ninety per cent of the artists met a cruel fate during the Pol Pot era and the few who survived set out to resurrect the lost art.

'I was like a smoker who gives up smoking', a well-known dancer said to me once, describing those years. 'I would dream of dance when I was alone or at night. You

7. In his book, Dancing in Shadows, Beeny Widyono refers to their political manoeuvring as "dancing in shadows in shaping the destiny of Cambodia" (3). 
could get through the day because of the hard work. It was the nights that were really difficult; we would lie awake wondering who was going to be called out next. That was when I would dance in my head'. (17)

Chea and dance teachers attempt to use classical dance to answer back to atrocity with profound discipline and transcendent beauty. Their dance performance is a means of rediscovering the exhilaration of expression. It is also interesting to imagine that need to answer back in Bakhtinian terms. In 'Art and Answerability,' Bakhtin posits: "I have an answer with my own life for what I have experienced and understood would not remain ineffectual in my life [...] Art and life are not one, but they must become united in the unity of my answerability" (1-2). Bakhtin's stress on the union of art and life through answerability is analogous to these Cambodian dance teachers' choice of expressing themselves through silence and dance, highlighting the relation between a classical form and a suppressed historical subject. Ghosh's travelogue illustrates how dance offers 'solidarity' and 'cultural continuity' to the survivors of the Khmer Rouge genocide. It testifies to how dancers rebuild their lives through the social and aesthetic force of performance to recreate new, diverse and compelling communities. By sharing the aesthetics of the art with the younger generation and by re-imagining the generative possibilities of Khmer culture, the dancers create formative spaces of hybrid identities and politics. Ghosh likens the survivors to ragpickers, sewing together lost links of family, home and lives from scanty remains (17-18). He superimposes architectural images of wreckage, delineating a society in ruins from collapsed heaps to dismantled scaffolding. Metaphors of destruction are followed by metaphors of construction as further images of assemblage (patchwork, sewing) suggest the possibility of creating a new yarn from old vibrant threads. Dance becomes the metaphor for resistance to violence and celebrates the triumph of the human spirit. ${ }^{8}$ Ghosh calls this act a "kind of rebirth: a moment when the grief of survival became indistinguishable from the joy of living" (52).

The second essay, "Stories in Stone", pays tribute to the architectural splendour of Angkor Wat, an ensemble dedicated to Vishnu and built by King Suryavarman II. ${ }^{9}$ Ghosh describes sacred temples that have survived the vicissitudes of history and relates the stories engraved on stone. Sculpture served as the fundamental art form for the Khmer kings to proclaim supremacy and represented a symbolic

8. The School of Fine Arts reopened in 1981, enrolling its first class of 111 students to train in the traditional arts. In 1980, the country's pro-Vietnamese government had already organized a national arts festival at Phnom Penh's Bassac Theatre in order to encourage artists to keep the dance form alive. Dance became a significant force, rejuvenating national pride and encouraging artistic and cultural rebirth for the people of Cambodia.

9. "Angkor refers to an area of 200 square kilometres in North-Western Cambodia. 'Angkor' is a Sanskrit word ('nagara') meaning 'holy city'. Angkor Wat is one of the temples in this region built by King Suryavarman who reigned from 1113-circa 1150 (Rooney 23). 
relationship between ruler and divinity. Ghosh underlines the fact that Cambodian dance remains etched in Khmer sculpture dating back to the ninth century. Traditional dance ballet as seen in architectural representations consists of a series of gestures and codified postures enacted to the choral chant of women and the rhythm of an orchestral beat. The ruler-divinity relationship lasted only during the king's reign and ceased at his death, but his predecessor had built temples, so that when he died another ruler started the temple building process anew. Even though a temple was never used for religious purposes by a succeeding ruler, Angkor Wat, the gigantic abacus of stories, continues to exist today to relate stories in stone to successive generations for centuries to come.

From the minute I first entered Angkor Wat I found myself awash in stories [...] This is true in a perfectly literal sense: with every step a visitor takes in this immense twelfth-century Cambodian temple he finds himself moving counters in a gigantic abacus of story-telling [...] But no story, no matter how loftily cosmic, is ever entirely free of its origins: as with all the best stories, this one too is partly an autobiography, an allegory about its own authorship. The chief protagonists in this instance are such imperial figures as King Suryavarman II, who was mainly responsible for building Angkor Wat, and JayavarmanVII, the megalomaniacal ruler who ruined his empire in trying to create the nearby complex of Angkor Thom. (54-55)

On this sculptured surface of stories and myths, the reader is drawn into an interesting game of hearing stories inscribed in the past. Deft moving of counters reveals new stories clamouring to be heard. Stories engraved on rock draw the reader into their web of heroic deeds. Etched in a kind of timeless memory, the stories depicted in Angkor Wat's magnificent bas-reliefs picture heroic deeds from the Mahabharatha such as Abhimanyu's trap in the death circle, and creation myths of the churning of the Sea of Milk. Ghosh deems these stories similar to those related by his grandmother as they swirl in a misty haze of forgotten memories, in sharp contrast to the vivacity of Cambodian storytellers to whom these stories in stone were vividly alive, related in the "confiding, urgent way in which people describe their neighbours' overheard quarrels" (55). Ghosh points to the historical paradox of the great twelfth-century temple whose images can be paired with emblems of the modernizing nation state.

For in the time I'd spent in Cambodia, I had made a discovery about Angkor Wat: I had discovered that its place in the world rests upon a kind of paradox. For many people, around the world, Angkor Wat is a uniquely powerful symbol of the romance of lost civilizations; of ancient glory, devoured by time. But for Cambodia it serves as no less a vivid symbol of modernity. Images of Angkor Wat are so common in Cambodia, so inescapable that after a while they become an assault upon the visitor's senses; the visual equivalent of radio-music played on public loudspeakers. There are so many of them, everywhere, that at first the images appear to be omnipresent, ubiquitous. But the impression is misleading; the images are not ubiquitous - in fact they are never where one expects. (55-56) 
The emblem connoting Cambodia's medieval history invades the visitor's senses since images of the Angkor Wat icon are featured on civil and military uniforms, factory articles, bottles of beer, on national and party flags, as logos for banks and even on the tail of the erstwhile Kampuchea airlines. Their visual impact can indeed be likened to the auditive and acoustic presence of modern radio music. Ghosh's essay recounts how the French discovery of Angkor Wat led to an archaeological invasion that separated the monument from local contact, lending room to materialism and cultural globalisation. The essayist shows how humanity draws inspiration from the cultural arts of the past and delves into the reasons for the stark differences between the glorious past history of Cambodia and its present-day chaotic world of oppression and strife. He aptly captures the dual picture of the romance of a lost civilisation and its mingling with the present day impact of technology and globalisation.

In the final essay, "At Large in Burma", Ghosh's travel account enables the reader to participate in the act of inter-cultural perception and construction. In English Travel Writing: From Pilgrimages to Postcolonial Explorations, Korte argues: "Travel writing provides us not only with an impression of the travelled world, but the travelling subject is always also laid bare: accounts of travel are never objective; they inevitably reveal the culture-specific and individual patterns of perception and knowledge which every traveller brings to the travelled world" (6). Having met Aung San Suu Kyi twice in captivity under house arrest in 1995 and 1996, Ghosh recalls his first interview with her during his student days at Oxford in 1980 in more tranquil times. The essay calls attention to her trajectory from obscurity to greatness and Ghosh lets his readers imagine her struggle for democracy in Burma with non-violence as her only tool. Ghosh admits having been brought up like Aung San Suu Kyi to "believe in the appropriateness of a strict separation between the public and the private, the political and the domestic" (83). He declares that it is wrong to categorise political movements with the ideology of one leader, but makes an exception with Aung San Suu Kyi whom he describes as "the personification of Burma's democratic resistance"(74).

The irony is that nothing better illustrates the passing of these values than Suu Kyis predicament. In the postmodern world, politics is everywhere a matter of symbols, and the truth is that Suu Kyi is her own greatest political asset. It is only because Burma's 1988 democracy movement had a symbol, personified in Suu $\mathrm{Kyi}$, that the world remembers it and continues to exert pressure on the current regime. Otherwise, the world would almost certainly have forgotten Burma's slain and dispersed democrats just as quickly as it has forgotten many others like them in the past. (83)

Ghosh records his impressions of the closed society of Burma, cut off from world politics by its dictator, General Ne Win, the leader of the Junta since 1962. The essay emphasizes the symbolic role played by Aung San Suu Kyi, the need to keep the quest for democracy alive in Burma, a country reduced from its former state 
of a golden land of plenty to a country where scarcity prevails in all domains. By describing the Karenni-refugee camps along the border between Burma and Thailand, Ghosh allows his readers to experience the journey along with him.

The hybrid travelogue is simultaneously an essay, a reportage, a sketch, a treatise and an account of various anecdotes and chance meetings. The chronicling bears the stamp of authenticity as it is both memoir and historiographical document. Ghosh notably gives an account of the historical guerrilla war waged for the last fifty years between the ethnic group of Karennis and the military Junta of Burma. He makes readers aware that the Karennis are now exhibits to hill tribe trekking tourists as they have been reduced to homelessness in camps. The essayist observes: "In effect tourism has transformed these camps, with their tragic histories of oppression, displacement and misery into counterfeits of timeless rural simplicity waxwork versions of the very past their inhabitants have irretrievably lost" (94). It is interesting to consider the processes by which Karenni camps are transformed into tourist attractions. In his study on the semiotics of tourism, Framing the Sign, Jonathan Culler explains that sights are dependent on markers: "empty sights become sights through the attachment of markers. An unremarkable piece of ground becomes a tourist attraction when equipped with a plaque $[. .$.$] and$ the markers themselves quite explicitly become the attraction, the sight itself" (165-166). Ghosh's analysis of the tourist code in the essay also foregrounds the interchangeability of 'signifier' and 'signified': the Karenni camp, originally a marker - a sign of homelessness and political turmoil - has become a site luring tourists into trekking up the hills to see the deplorable state of lost civilisation.

One of the striking aspects of Ghosh's travelogue is the openness with which he draws attention to the political issues of the landscape. Metaphors of dance and sculpture play a vital role in reporting and 'textualizing' the journey. As Korte remarks in English Travel Writing: From Pilgrimages to Postcolonial Explorations, "If the journey is found to be significant, this often happens not during the act of travelling itself, but rather at the moment when the journey is textualised. Meaningful travelling experience, for many postmodern travellers, will only emerge with the act of travel writing" (144). Ghosh's travelogue offers just such a meaningful commentary on the political, social and economic situation of Cambodia and Burma. In an interview with Subash Jeyan in The Hindu Literary Review, Ghosh comments on what it means to be a writer today in a globalized world: "For me, having travelled abroad, one of the most instructive things about India is the realisation that India is really not a place located within India as it were; for two hundred years now, it's also been an experience of the world you know; it's been an experience of Mauritius, or Malaysia, or Burma. And this is what interests me most now; the ways in which India came to be, as it were, dispersed" (1). Ghosh's essay relates how the boundaries of nation states are apparently melting, a characteristic of the postcolonial travelogue. Strands typical of the postcolonial condition can be identified in the writer's need to discover, explore and travel the world, in particular to regions that bear traces of the postcolonial condition. 
'Displacement', as Bhabha posits in The Location of Culture, is an experience typical of the postcolonial condition, which bursts forth in situations of migration, expatriation, diaspora and exile. Bhabha contends that 'displacement' enables the postcolonial migrant to study the "situational representation on the part of the individual to that vaster and unrepresentable totality which is the ensemble of society's structures as a whole" (217). By modifying modes of travel established by English-speaking writers with paths traced from the West to the East, Ghosh's travelogue inverts the paths traced by the coloniser, by charting a new course of exploration of South East Asia, consciously reversing canonised patterns of travel from imperial centre to colonial periphery. Ghosh gives a voice to accounts that clamour for attention, but remain lost to the present-day world. He operates in the manner of the postcolonial travel writers whom Korte has identified as manifesting a "strong political interest and a special sensitivity to the mechanisms of power" (Korte 165). Ghosh's project of writing back to the centre is typical of the postcolonial phenomenon posited by Bhabha in which "the margins of the nation displace the centre; the peoples of the periphery return to rewrite the history and fiction of the metropolis" (Bhabha 1990 6). As a "Third World' writer with an international background, Ghosh is the migrant writer who dispenses with narrow territorial affiliations, travels without fetters of political ideology through the cultures of the world, and pens his experiences. Ghosh's travelogue is enriched by the quest to discover the sensitivities of displaced and dispossessed voices of people suppressed by coercive forces of colonialism and nationalism.

Suhasini VINCENT

Université Paris 2 - Panthéon-Assas

\section{Works Cited}

Bakhtin, Mikhail. Art and Answerability: Early Philosophical Essays. Ed. M. Holquist and V. Liapunov. Austin: U of Texas P, 1990.

Barthes, Roland. 'The Grain of the Voice.' 1985. In The Responsibility of Forms. Trans. R. Howard. New York: Hill \& Wang, 1991. 267-77.

Bнabha, Homi, ed. Nation and Narration. 1990. London: Routledge, 1994.

- The Location of Culture. London: Routledge, 1994.

Braquet, Sébastien. Cambodge : Les Clés d'un Royaume. Jouy-sur-Morin: Editions Pages du Monde, Collection Anako, 2007.

Culler, Jonathan. Framing the Sign: Criticism and its Institutions. Oxford: Basil Blackwell, 1988.

Grosh, Amitav. Dancing in Cambodia, At Large in Burma. New Delhi: Ravi Dayal, 1998. 
Hamera, Judith. Dancing Communities: Performance, Difference and Connection in the Global City. New York: Palgrave Macmillan, 2008.

JeYan, Subash. "India and its Locations." The Hindu Literary Review (3 September 2006): 2 .

Korte, Barbara. English Travel Writing: From Pilgrimages to Postcolonial Explorations. 1996. Trans. Catherine Mathias. New York: Palgrave, 2008.

Vieville, Dominique, ed. Rodin et les danseuses cambodgiennes : Sa dernière passion. Paris: Editions du Musée Rodin, 2006.

Rooney, Dawn, F. Angkor: Cambodia's Wondrous Khmer Temples. Fifth Edition, Hong Kong: Odyssey, 2006.

Widyono, Benny. Dancing in Shadows: Sihanouk, The Khmer Rouge, and the United Nations in Cambodia. Lanham: Rowman \& Littlefield Publishers, 2008. 